\title{
Reassessment of morphology and historical distribution as factors in conservation efforts for the Endangered Patagonian Huemul Deer Hippocamelus bisulcus (Molina 1782)
}

\author{
Huemul Task Force * \\ International Union for Conservation of Nature (IUCN), Species Survival Commission (SSC), Clo Chair, C.C. 592 , 8400 Bariloche, \\ Argentina, \\ Email: HTF@deerlab.org
}

Date of publication (online): 26 November 2012 Date of publication (print): 26 November 2012 ISSN 0974-7907 (online) | 0974-7893 (print)

Editor: Norma Chapman

\section{Manuscript details:}

Ms \# 03088

Received 30 January 2011

Final received 22 October 2012

Finally accepted 24 October 2012

Citation: Huemul Task Force (2012). Reassessment of morphology and historical distribution as factors in conservation efforts for the Endangered Patagonian Huemul Deer Hippocamelus bisulcus (Molina 1782). Journal of Threatened Taxa 4(14): 3302-3311.

Copyright: @ C Huemul Task Force 2012. Creative Commons Attribution 3.0 Unported License. JoTT allows unrestricted use of this article in any medium for non-profit purposes, reproduction and distribution by providing adequate credit to the authors and the source of publication.

Acknowledgements: The Huemul Task Force would like to thank the non-author group members: Paulo Corti, Robin Gill, William McShea, and Cristian Saucedo.

* Individual authors: Eduardo G. Aisen, Fernando Vidal, Gladys Garay, Jaime E. Jiménez, Jo Anne Smith-Flueck, Norberto Tomas, Patricia Black de Decima, Valerius Geist, Werner Flueck, Zygmunt Gizejewski.

urn:Isid:zoobank.org:pub:06EA2E12-F32140B3-BE88-86B86A2CE2BB

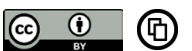

OPEN ACCESS | FREE DOWNLOAD
Abstract: To assist with conservation of Endangered Patagonian Huemul Deer (Hippocamelus bisulcus), the Huemul Task Force (HTF) reassessed information on appendicular morphology, paleobiogeography, and historical distribution as potential factors in recovery efforts. Traditional claims of being a mountain specialist of the Andes were refuted by empirical evidence showing huemul morphology to coincide with other cervids rather than the commonly implied homology to rock-climbing ungulates. It thus supports historical evidence of huemul in treeless habitat and reaching the Atlantic coast, which cannot be dismissed as past erroneous observations. Instead, pre- and post-Columbian anthropogenic impacts resulted in huemul displacement from productive sites and in survival mainly in remote and marginal refuge areas. The process of range contraction was facilitated by easy hunting of huemul, energetic incentives from seasonal fat cycles and huemul concentrations, the change from hunting-gathering to a mobile equestrian economy, and colonization with livestock. However, areas used presently by huemul, as supposed mountain specialists, are also used by wild and domestic ungulates that clearly are not considered mountain specialists, whereas the only other Hippocamelus successfully uses areas homologous to tree-less Patagonia. Rigid application of modern habitat usage to infer past habitat use and ignoring historic extra-Andean accounts is unwarranted; these conclusions reached by the HTF indicate new opportunities for recovery efforts by considering morphological and historical evidence. For instance, reintroductions to other portions of the landscape used formerly by huemul, which tend to be more productive sites than those currently occupied by many huemul groups, would present a promising avenue.

Keywords: Adaptation, Andes mountains, appendicular morphology, biogeography, Hippocamelus bisulcus, historical condition, human influence, range contractions, skeletal ratios.

\section{INTRODUCTION}

In recognition of the urgency of the crisis regarding the Endangered Patagonian Huemul Deer Hippocamelus bisulcus, the Huemul Task Force (HTF) was formed within the IUCN-SSC to create another tool to provide recommendations and guidelines based on sound scientific information through which the recovery of Huemul can be achieved. Aside from assisting to determine the current status of Huemul and review the existing knowledge base, the aim is to identify scientifically acceptable methodology appropriate for the species' recovery.

Although Diaz (1993) showed already then how history erroneously 'led to the assumption that the Huemul was a deer of the mountains and that it had always inhabited areas in proximity to rugged topography', the importance of this fact has remained largely unrecognized, and remnant

Abbreviations: HTF - Huemul Task Force; IUCN - International Union for Conservation of Nature; SSC - Species Survival Commission 
populations in mountain sites are commonly interpreted to be due to Huemul being particularly adapted to such sites, which thus supposedly represent prime habitat for the species. Moreover, Huemul being a mountain deer is often reiterated and supported by referencing key paleontological work, a study which, however, was erroneous (see below). Main results of these historic influences are 3 -fold, by fomenting persisting claims that: (i) Huemul are exclusively a mountain deer, specialized to rugged terrain; (ii) that their natural range are the Andes mountains, as evidenced by the current relict distribution; and (iii) that the few historic accounts of extra-Andean presence were thus erroneous, or unimportant outliers. As interpretations of the biology and ecology of Huemul play a mayor role in conservation strategies, the HTF worked systematically through available evidence to evaluate common depictions of this species.

\section{METHODS}

Beginning in June of 2008, a diversity of data from various published and unpublished sources were analyzed to address the questions if Huemul specifically is a mountain deer, and if historic reports of extraAndean Huemul can legitimately and universally be dismissed as erroneous observations of past naturalists. The HTF formulated several conclusions below.

\section{RESULTS AND DISCUSSION}

\section{Huemul as mountain deer}

Early European explorers and naturalists described Huemul as stocky, massive and short-legged deer of mountains, comparing them to Ibex Capra ibex and Chamois Rupicapra rupicapra in their homeland (e.g., Krieg 1925; Kurten 1979). They assumed Huemul to be a mountain deer, just as was the interpretation for Ibex and Chamois at that time, ungulates which by then were mainly surviving in remote alpine areas. Similarly, early North American workers compared Huemul to Mountain Sheep Ovis canadensis and Mountain Goats Oreamnos americanus (e.g., Krieg 1925; Frers 1969). More recent authors, often referring to these early writings, make similar statements. However, early writings about Huemul generally already reported their rareness, disappearance or near extinction (e.g., Philippi 1857; Gigoux 1929), and references to stocky and short-legged Huemul were casual remarks made about deer found mainly in refuge areas. Moreover, behavior like the aggressive horseshoe stance (Cowan \& Geist 1961) and thick long hair (Image 1) dissimulate stockiness by distorting body shape (reviewed in Flueck \& Smith-Flueck 2011).

Anew fossil of North American cervid Navahoceros was described by Kurten (1975) as having 'highly unusual adaptive characters' among cervids, interpreted as extreme adaptations to mountains, and resulting in its common name 'mountain deer'. He explicitly compared it to alpine Chamois and Ibex, and considered Hippocamelus as related to his fossil. Even though his fossil species has since been shown to be a construct and declared a 'nomen nudum' (Morejohn \& Dailey 2004), this relationship is still cited in arguing that Huemul is a mountain deer. The only comparative osteological analysis on leg morphology of Huemul and 12 other ungulates revealed that Huemul cannot be associated with rock climbing species. Although intraspecific proportional leg length is influenced by ecogeography, nutrition, physiology and factors affecting exercise, with variances of up to $70 \%$ in better studied cervids, Huemul morphology does not overlap with rock climbing species previously considered analogous, but falls within the range of other cervids (Flueck \& Smith-Flueck 2011).

Position about Huemul not being a mountain deer, adopted by the HTF in 2011:

1. Early historical descriptions of Huemul as short-legged mountain deer comparable to Ibex, Chamois, Bighorn Sheep, or Mountain Goats were only casual comments. The descriptions likely resulted from thick hair coats ( $7-9 \mathrm{~cm}$ hair length) and the behavior of using the horseshoe posture.

2. Kurten's technical paleontological paper (1975) established Navahoceros as a mountain deer comparable to Ibex and Chamois: Navahoceros has been shown to be a 'nomen nudum' (as was concluded earlier for Kurten's Stilt-legged Deer, Sangamona). Kurten's referring to Hippocamelus as related to the ancestral Navahoceros (only differing by having two [erroneous], instead of three antler tines), has been rejected based on revising all bones and assembled skeletons labeled as Navahoceros, which were confirmed to be Odocoileus (Morejohn \& Dailey 


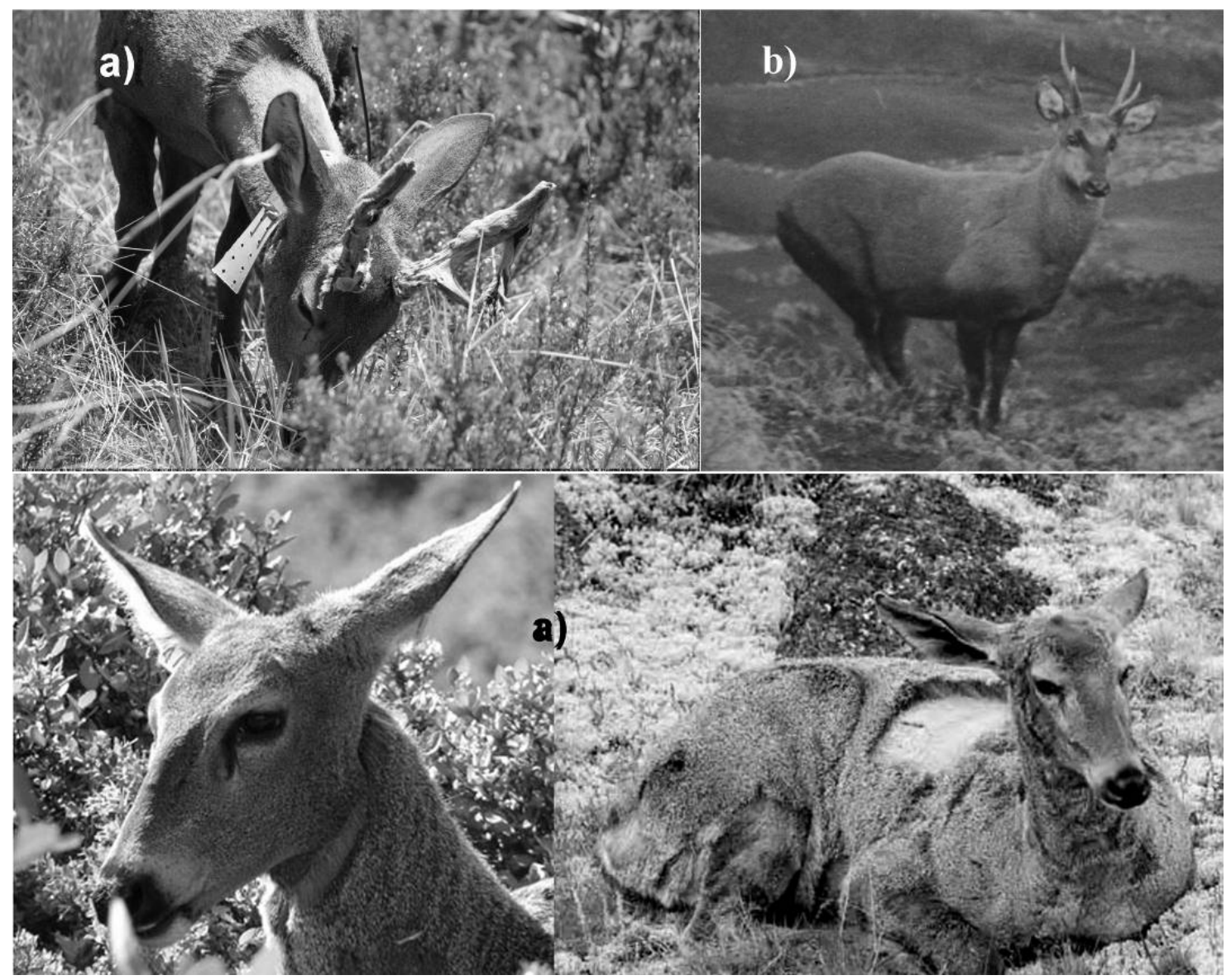

Image 1. (a) The 7-9-cm-thick hair coat is best appreciated when being shed. Note in the upper and lower left photos that the diameter of the upper neck is substantially less than further down in the unshed portion. (b) The aggressive stance of huemul at close range, known as the horseshoe posture.

2004).

3. The morphometric analysis of complete leg assemblies from Huemul, then compared to several other species, shows that Huemul completely differ from ungulates considered rock climbers. Furthermore, intraspecific variation in proportional leg length - largely due to ecogeographical rules and nutritional and physiological limitations - is up to $70 \%$ and results in populations of Rangifer and even O. virginianus having much shorter legs (by 14\%) than the Huemul sample.

4. The nutritional ecology and climatic and topographic features of localities where Huemul currently remain indicate that leg proportions from these sites would be at the low end of the range of variations for Huemul: irrespectively, these proportions clearly fall within the range of other cervids (Image 2). Taruca (H. antisensis) - the only sister species to Huemul - utilizes some forest types, but is currently mainly found in treeless grasslands with high affinity to Patagonian grasslands, coexisting with several camelid species.

\section{Past distribution of Huemul}

The pre-Columbian distribution of Huemul has its roots in founding stock, likely of the Odocoileus line (Morejohn \& Dailey 2004), which dispersed through the Panama land bridge during the Great American Interchange. Having to pass this equatorial filter of continuous savanna habitat, succeeding species were generalists and predominantly savanna-adapted (Webb 1978). As reviewed in Flueck \& Smith-Flueck (2012), Hippocamelus were established by the Pleistocene, having dispersed south on the eastern side of the Andes through continuous savanna habitat. Several periods of glaciation kept ancestral Hippocamelus repeatedly away from the Andes, and fossils are even known as far northeast as $8^{\circ} 9^{\prime} \mathrm{S} \& 36^{\circ} 22^{\prime} \mathrm{W}$ in the most eastern tip of Brazil, and from the plains of Argentina, Uruguay and southeastern Brasil. 


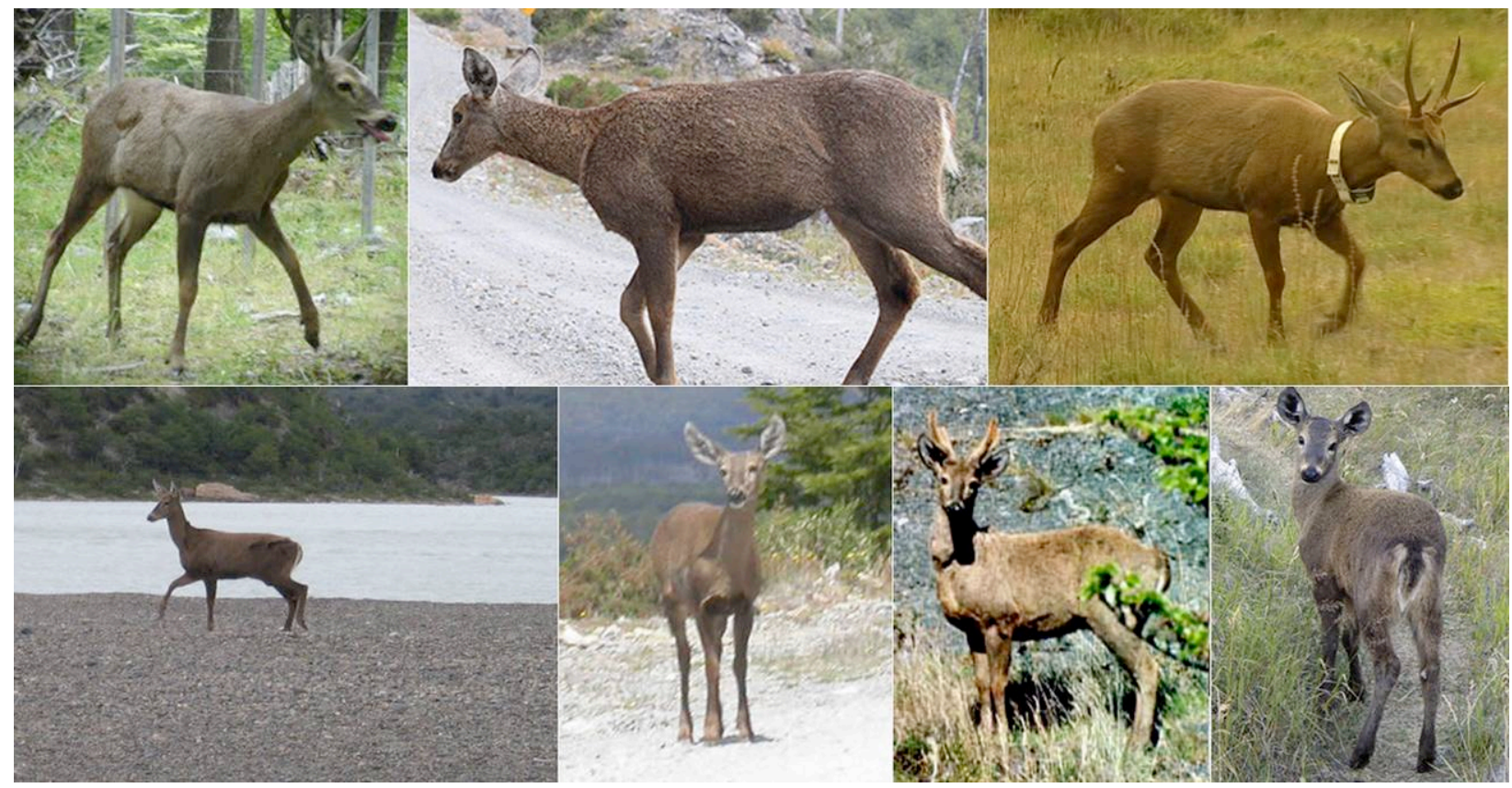

Image 2. Body shapes of several extant Huemul that are not in an alert stance and with summer coat.

During glacial periods, the Andes were covered with ice even to near the equator, and a continuous sheet covered the mountains from $33-56^{\circ} \mathrm{S}$ during the last glacial maximum. Glaciers south of $42^{\circ} \mathrm{S}$ dipped into the Pacific, overlaid the Andes 1600-1800 $\mathrm{m}$ thick, and reached hundreds of kilometers into eastern Patagonian plains where only treeless habitat existed, with Patagonia-like grasslands reaching way into Brazil, and much of South America covered by savannah and grasslands. Moreover, the sea level was about $120 \mathrm{~m}$ lower and the Atlantic coastline located $300 \mathrm{~km}$ or more to the east of the present coastline in some latitudes, which greatly extended the flat paleosteppe region eastwards (e.g., Marshall 1988; Clapperton 1993; Markgraf \& Kenny 1997).

During glaciations, Hippocamelus thus persisted in eastern treeless lowlands reaching the plains of Uruguay, northern Argentina and Brazil. As mixed feeders, Huemul can incorporate notable amounts of grass in the diet. Furthermore, besides Graminae, Patagonian steppes contain large components of shrubs, maintain important green grass production throughout winter, and deer are known to make much use of seed heads, which further corroborates past and even historic distributions of Huemul in non-forested habitats. Once eastern foothill regions became glacierfree, Huemul were able to reach Andean habitat and when deglaciation allowed for it, eventually to cross the Andes. Faunal exchanges from the east were foremost across low Andean passes and explain the occurrence of late Pleistocene Huemul in Chile as far northwest as $30^{\circ} \mathrm{S}$ by the Pacific coast (e.g., Ochsenius 1985; Moreno et al. 1994). With the last glacial retreat, forests spread from few western refuges, and eventually covered the southern Andes again, reaching their current extent only 2-3000 ya.

Nomadic hunter-gatherers arriving in the southern Andes with the last interglacial period would have had some influence on local distribution of Huemul. However, in northern and central Chile, human adopted sessile and agricultural lifestyles long before arrival of the Spanish, reaching very high densities, completely changing habitat through slash and burn, and regionally extirpating several species including Huemul and Pudu Deer Pudu puda. Further south, humans became established mainly along the Pacific coast and focused on marine resources. Consequently, early explorers still found coastal areas abundant with Huemul. East of the Andes, Huemul then also existed in zones between the Andean foothills and the Patagonian mesas, still regularly occurring in flat grasslands about $120 \mathrm{~km}$ east of the Andes, and already more rarely, up to another $140 \mathrm{~km}$ further east. Several reports show this species to have reached the Atlantic coast (e.g., MacDouall 1833; Moreno 1899).

The Spanish arrival resulted in highly significant 
changes brought about by the introduction of horses, which created an equestrian lifestyle for native people and profoundly changed their economies. Liberated in Buenos Aires, feral horses already reached the Strait of Magellan by 1580 . Livestock also became feral immediately and soon roamed by the millions. Darwin (1839) found that native people knew how to use knives, forks, spoons and relished sugar, and most of the men spoke some English and Spanish. He further noted that these natives travelled up to $750 \mathrm{~km}$ inland during summer to hunt in the foothills, each man having 6-7 horses. Native tribes dominated the region for some 300 years until displaced by wars, followed by the colonization of Patagonia with fencing and ranching occurring rapidly throughout the region, and with over $47 \%$ of Patagonian forests burnt before 1914 (e.g., Willis 1914).

As a result of the above-mentioned history, the first early writings were posterior to significant anthropogenic changes in the distribution of Huemul, with explorers therefore largely unaware of previous history. Their descriptions of Huemul often were from remnant populations living in remote and inaccessible places. Subsequent naturalists found an even more reduced distribution, but as locations coincided with the few early accounts, it led to dogmatic descriptions. Thus, decades have gone by further ingraining the notion that Huemul are exclusively of Andean forests and not part of lowland central Chile; specially adapted to precipitous rocky terrain, and forest habitats of the Andes; a Mountain Deer living above tree line; only living between 1300-1700 m or high elevation mountains; or as preferring steep, rocky, north-facing slopes. Preference to the high Andes, principally near the international border along the continental divide, was considered explicitly to be due to the conditions in that area being the most favorable to Huemul (e.g., Osgood 1943).

The fact that native people may have influenced Huemul distribution, including after the increase in mobility due to horses, has been discounted based on the argument that Huemul were energetically uninteresting. However, dissectable fat of deer contains up to $47 \%$ of total energy content, whereas marrow fat adds only $1 \%$ more, explaining why huntergatherers focus on deer during the autumn/winter peak of fat (e.g., Thomas \& Toweill 1982; Lipo 2007). This has been ignored when claiming that hunter-gatherers would not have used an animal so lean as the Huemul, this reasoning being based only on marrow fat. In contrast, while butchering, natives of northern North America consumed dissectable fat and transported remaining bones for marrow and tallow extraction at camp, just as documented for Patagonian huntergatherers: but the few bone remains found in old shelters only provide a partial picture. It is erroneous to ignore that professional hunter-gatherers would certainly have taken advantage of easy accessible fat which presents $>1200 \%$ more energy content than that obtained from bones. Hunter-gatherers, commonly moving according to seasonal movements of prey, covering distances up to $150 \mathrm{~km}$ for hunting particularly in autumn and early winter, best explained logistical mobility in low-density hunter-gatherers in northern environments. From hunting camps, groups of young men would make roundtrips of $>100 \mathrm{~km}$ in about three days, being able to portray detailed maps covering $240,000 \mathrm{~km}^{2}$ and animal movements within. Deer being preferred, a temporary camp would remain if there were animals within $50 \mathrm{~km}$. Taking this in account when considering historic reports of winter concentrations of Huemul, foraging conditions in the pre-Colombian era were likely even superior to historic times in terms of significance to hunter-gatherers. Borrero (2008) acknowledged that so far surveys in Patagonia had been biased, being focused on caves that represent permanent sites. Transient hunting camps and movements are thus under-represented and difficult to document anyway.

Position about the past distribution of Huemul, adopted by the HTF in 2011:

1. Likely it was Odocoileus lucasi (viz., Navahocerus nomen nudum) dispersing through the Panama land bridge, savanna-adapted by necessity via that equatorial filter, and giving rise to Hippocamelus.

2. Glaciations prevented the continuous use of Andean highlands and the Pacific side: during glaciations, Patagonia-type habitat, and fossil Hippocamelus reached into northeastern Brazil; Patagonia was twice the current size, as the Atlantic coast line was hundreds of kilometers further east due to much lower sea levels.

3. Dispersal and colonization likely occurred along the eastern fringe of the cordillera and a coastal route (e.g., Marshall 1988). Similarly, bighorn 
sheep remained in grassland and steppe areas during glaciation, then followed as glaciers retreated; colonization is considered to have likely occurred along cordillera going south, along glacial margins in habitats like tundra and taiga (Geist 1985).

4. After the last glaciation, forests spread from Pacific refuges and covered the southern Andes again, reaching their current extent only 2-3000 ya. Once ice-free, low passes allowed Huemul to enter from the east and to populate landscapes also west of the Andes.

5. Humans arrived with the last interglacial period, about 10-12000 ya in the southern Andes. PreColumbian hunter-gatherers likely had local impacts on Huemul distribution based on optimal foraging among studied hunter-gatherers (including behavior of Patagonian natives regarding Guanaco Lama guanicoe), seasonal fat cycle in Huemul, easiness to hunt Huemul in autumn/winter. Pre-Columbian sessile natives in central Chile exterminated local fauna including cervids like pudu and Huemul.

6. Post-Columbian natives became equestrian, focusing on feral domestic livestock and native ungulates. Patagonians traveled up to $750 \mathrm{~km}$ to hunt in eastern ecotone and foothills, burning extensive landscapes. Similarly on the Chilean side, large numbers of livestock and equestrian people displaced Huemul such that early on Huemul were considered rare and restricted to steep remote mountain areas (except in southern distant Fiord areas).

7. After 300 years of dominance, the natives on the eastern side of Andes were subdued and a wave of fencing and ranching went through Patagonia, with heavy impact on the few Huemul remaining on those lands.

8. Due to pre- and post-Columbian events, the first writings were posterior to significant anthropogenic changes in Huemul distribution, with descriptions from remnant Huemul populations living mainly in remote and inaccessible places. Similarly for desert bighorn sheep, rather than becoming a relict species created by post-pleistocene ecological changes, they have become secondary relicts with small, isolated populations created by the impact of European settlement as early as 1540 . The overall result was the extirpation of many populations of bighorn and the creation of smaller, isolated herds, prone to extinction (McCutchen 1982).
9. As a result of pre- and post-Columbian events, there are few historic documents of Huemul still existing in extra-Andean landscapes, however:

- there were still several reports about large groups in traditional wintering areas, i.e. groups of 100 or more

- today mainly forked antlers occur, yet there are several reports of 4 and 5 point antlers, i.e. prior habitat sites were superior to extant sites (the newest rediscovery of this fact: de la Croix 1937)

- besides thorough reviews by Diaz (1993, 2000) there are several newly discovered sources including photos of hunted Huemul, with distances from the Andes at $120 \mathrm{~km}, 200 \mathrm{~km}, 260 \mathrm{~km}, 270 \mathrm{~km}$, and all the way to the Atlantic coast (Image 3 ).

Note: there are several lines of evidence that Huemul also occurred in Tierra del Fuego (see Flueck \& SmithFlueck 2012).

\section{CONCLUSIONS}

The few historic accounts still documenting presence of Huemul in the eastern treeless lowlands, indicate that Huemul were well suited to exploit those areas. This information cannot be dismissed due to its relevance, similarly as had been shown for Chamois and Ibex. By avoiding the application of analogies based only on the present situation, but beginning to use comparative morphometry and the past to understand the presence, the repeated fallacy of simply imposing the present on the past will be omitted. The empirical comparisons showed Huemul leg morphology to fall well within that of other cervids and can be expected to vary substantially if they were to live in habitats formerly used. It supports the evidence that Huemul existed in treeless habitat and colonized Andean forests and higher altitudes secondarily, and habitat breadth of Huemul is thus more like that found in other closely related Odocoilines, and moreover, coincides with habitat use by the only congeneric, the taruca. Although Huemul can use forests exclusively, they can also thrive in ecotone, and (previously) in grasslands, steppe, and deserts (like Odocoilines, Ibex, Bighorn Sheep, Red Deer Cervus elaphus, Guanaco). Additionally, unspotted Hippocamelus fawns also point to an origin in non-forested areas, which still 


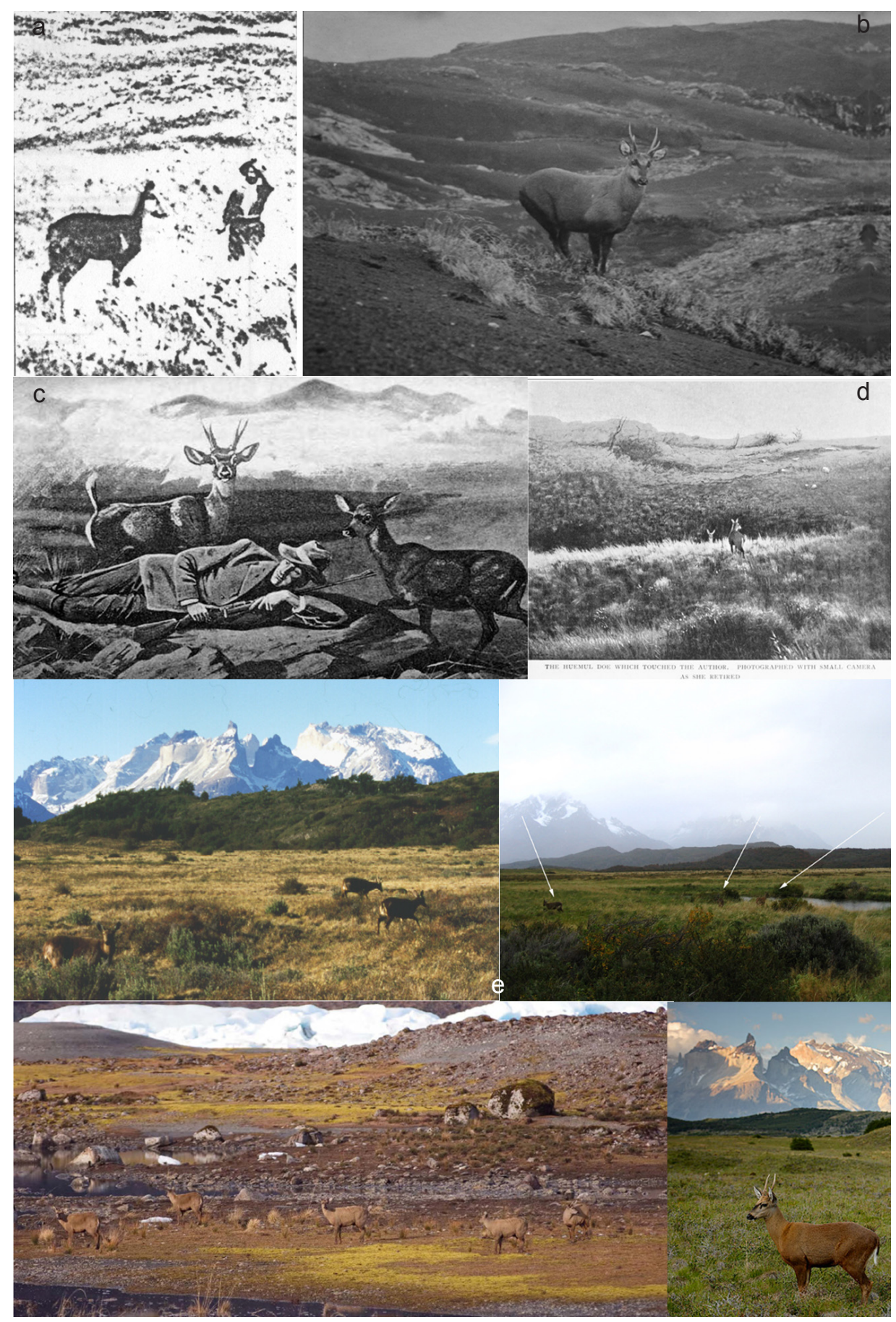

Image 3. Huemul habitat far from forests and in flat or rolling landscapes. (a) Huemul in steppe, approached by gaucho, from Onelli 1904. (b) Huemul photographed in the 1920 s by A. Grosse. (c,d) Princeton expeditions, late 1800s, hunting huemul as far as $200 \mathrm{~km}$ from forests, from Hatcher 1903. (e) Extant Huemul in periglacial Pacific coast, old moraines, and flat wide valley bottoms. (note: open areas used during midday hours)

presents the principal habitat use by $H$. antisensis. Moreover, even small cervids thrive exclusively in treeless grasslands, like Pampas Deer (Ozotoceros bezoarticus Perez et al., 2008) or Roe Deer (Capreolus capreolus Abbas et al., 2012), which show extensive digestive plasticity via behavioral and morphological adaptations.

The seasonal fat cycle and congregations likely made Huemul a prime candidate for hunter-gatherers, who would have therefore influenced their distribution and density. The subsequent equestrian mobility of natives and later colonists further displaced Huemul 
from traditional valleys and winter ranges. Several other ungulates had mainly lost their low elevation habitats from anthropogenic pressures and range contraction allowed them to persist only in marginal peripherical habitat, concentrated at high elevations or otherwise inaccessible sites (Channell \& Lomolino 2000; Laliberte \& Ripple 2004). Thus, paleoecology, zoogeography, and history of land use in southern Latin America indicate that Huemul exclusively remaining in high mountains are secondary relicts created by post-Columbian anthropogenic impacts. The presence of Huemul right into historic times in grasslands and steppe areas is likely of more importance to Huemul conservation than hitherto acknowledged.

Although Huemul presently still use flat areas, they did more so in the past (like Odocoilines, Bighorn Sheep, Guanaco, but unlike Mountain Goat, Ibex). The habitat types used by Huemul in recent times and resulting in the colloquial description as mountain deer, are not preventing the use of these areas by species not considered mountain specialists, like Guanaco, Wild Boar Sus scrofa, Red Deer, Fallow Deer Dama dama, cattle (specially feral ones), goats, sheep, and horses. The habitat types used by Huemul historically are also used by these same species above. Taruca, considered by several authors osteologically indistinguishable from Huemul and suggested to represent two subspecies, occur in areas used by camelids (vicuña, guanaco, llamas, alpacas), WhiteTailed Deer Odocoileus virginianus, domestic sheep, cattle, horses, and mules. Taruca occur in the cold desert 'puna', which includes large tracks of plains (altiplano): nearly every one of its plant genera also occurs in the Patagonia steppe (Fernández \& Busso 1997). Lastly, taruca also occur in ecotone and forests (still now, but more so in the past).

The rigid application of modern Huemul habitat usage to infer past habitat use and ignoring historic extra-Andean accounts as erroneous or abnormal outliers is unwarranted. The conclusions reached by the HTF indicate new opportunities for recovery efforts by considering morphological and historical evidence. For instance, reintroductions to other portions of the landscape used formerly by Huemul, which tend to be more productive sites than those currently occupied by many Huemul groups, would present a promising avenue (see IUCN 2012 in prep.: Guidelines for Reintroductions and otherConservation Translocations.
IUCN/SSC Reintroduction and Invasive Species Specialist Groups. IUCN, Gland, Switzerland). Although adopting a uniform conservation program over a large geographical area is attractive to policymakers and conservation planners, the large range of past geographical and ecological sites used by Huemul indicate that conservation programs could benefit from broadening strategies accordingly.

\section{REFERENCES}

Abbas, F., D. Picot, J. Merlet, B. Cargnelutti, B. Lourtet, J. Angibault, T. Daufresne, S. Aulagnier \& H. Verheyden (2012). A typical browser, the roe deer, may consume substantial quantities of grasses in open landscapes. European Journal of Wildlife Research DOI 10.1007/ s10344-012-0648-9.

Borrero, L.A. (2008). Early occupations in the southern cone, pp. 59-77. In: Silverman H. \& W. Isbell (eds.). Handbook of South American Archaeology. Springer, New York.

Channell, R. \& M.V. Lomolino (2000). Dynamics biogeography and conservation of endangered species. Nature 403: 84-86.

Clapperton, C.M. (1993). Nature of environmental changes in South America at the Last Glacial Maximum. Palaeogeography, Paleoclimatology, Palaeoecology 101: 189-208.

Cowan, I.McT. \& V. Geist (1961). Aggressive behavior in deer of the genus Odocoileus. Journal of Mammalogy 42: 522-526.

Darwin, C. (1839). Narratives of the Surveying Voyages of the Adventure and Beagle. Volume III. Henry Colburn: London.

de la Croix, P.M. (1937). El huemul. Caras y Caretas (Buenos Aires) 40(2001): 117

Díaz, N.I. (1993). Changes in the range distribution of Hippocamelus bisulcus in Patagonia. Zeitschrift für Säugetierkunde 58: 344-351.

Díaz, N.I. (2000). The Huemul (Hippocamelus bisulcus Molina, 1782): A historical perspective, pp. 1-31. In: Díaz, N.I. \& J.M. Smith-Flueck (eds.) The Patagonian Huemul. A Mysterious Deer on The Brink of Extinction. Literature of Latin America: Buenos Aires.

Fernández, O.A. \& C.A. Busso (1997). Arid and semi-arid rangelands: two thirds of Argentina, pp. 41-60. In: Arnalds, O. \& S. Archer (eds.) Proceedings from an International Workshop in Iceland. Rala Report no. 200. Agricultural Research Institute: Reykjavik, Iceland.

Flueck, W.T. \& J.M. Smith-Flueck (2011). Osteological comparisons of appendicular skeletons: a case study on Patagonian Huemul Deer and its implications for conservation. Animal Production Science 51: 327-339.

Flueck, W.T. \& J.M. Smith-Flueck (2012). Huemul heresies: 
beliefs in search of supporting data. 1. Historical and zooarcheological considerations. Animal Production Science 52: 685-693.

Frers, K.A. (1969). Das Waidwerk und die autochthonen Cerviden in Argentinien, pp. 25-31. In: Vogel, C.A. (ed.) Parque Diana. Stefan Schwarz Verlag: München, Germany.

Geist, V. (1985). On pleistocene bighorn sheep: some problems of adaption, and relevance to today's American megafauna. Wildlife Society Bulletin 13(3): 351-359.

Gigoux, E.E. (1929). El huemul. Revista Chilena de Historia Natural 23: 573-82.

Grosse, A. (1949). El huemul - ciervo de los Andes y emblema del escudo Chileno. Condor (Revista Chileno Alemana) 12 $10-12$.

Hatcher, J.B. (1903). Reports of the Princeton University expeditions to Patagonia, 1896-1899. Vol. I: Narrative of the Expeditions. Geography of Southern Patagonia. E. Schweizerbart'sche Verlagshandlung: Stuttgart.

Krieg, H. (1925). Biologische Reisestudien in Südamerika. V. Die chilenischen Hirsche. Zeitschrift für Morphologie und Oekologie der Tiere 4: 585-97.

Kurten, B. (1975). A new Pleistocene genus of American mountain deer. Journal of Mammalogy 56: 507-508.

Kurten, B. (1979). A stilt-legged deer Sangamona of the NorthAmerican Pleistocene. Boreas 8: 313-321.

Laliberte, A.S. \& W.J. Ripple (2004). Range contractions of North American carnivores and ungulates. BioScience 54: 123-138.

Lipo, K.D. (2007). Evolutionary foraging models in zooarchaeological analysis: Recent applications and future challenges. Journal of Archeological Research 15: 143189.

MacDouall, J. (1833). Narratives of A Voyage to Patagonia and Terra del Fuego. Renshaw and Rush, London, 320pp.

Markgraf, V. \& R. Kenny (1997). Character of rapid vegetation and climate change during the late-Glacial in southernmost South America, pp. 81-90. In: Huntley, B. (ed.) Past and Future Rapid Environmental Changes:
Spatial and Evolutionary Responses to terrestrial Biota. Springer-Verlag, Berlin.

Marshall, L.G. (1988). Land Mammals and the Great American Interchange. American Scientist 76: 380-388.

McCutchen, H.E. (1981). Desert Bighorn Zoogeography and Adaptation in Relation to Historic Land Use. Wildlife Society Bulletin 9(3): 171-179.

Morejohn, G.V. \& D.C. Dailey (2004). The identity and postcranial osteology of Odocoileus lucasi (Hay) 1927. Sierra College Natural History Museum Bulletin 1: 1-54.

Moreno, P.I., C. Villagran, P.A. Marquet \& L.G. Marshall (1994). Quaternary paleobiogeography of northern and central Chile. Revista Chilena de Historia Natural 67: 487-502.

Moreno, F.P. (1899). Explorations in Patagonia. The Geographical Journal 14: 241-269.

Ochsenius, C. (1985). Pleniglacial Desertization, large-animal mass extinction and Pleistocene-Holocene boundary in South America. Revista de Geografia Norte Grande 12: 35-47.

Onelli, C. (1904). Trepando los Andes. Companía SudAmericana de Billetes de Banco: Buenos Aires, 297pp.

Osgood, W.H. (1943). The mammals of Chile. Field Museum Natural History, Zoological Series 30: 1-268.

Perez, W., M. Clauss \& R. Ungerfeld (2008). Observations on the macroscopic anatomy of the intestinal tract and its mesenteric folds in the Pampas Deer (Ozotoceros bezoarticus, Linnaeus 1758). Anatomia, Histologia and Embryologia 37: 317-321.

Philippi, R.A. (1857). Über den Guemul von Molina. Archiv für Naturgeschichte 23: 135-136.

Thomas, J.W. \& D.E. Toweill (1982). Elk of North America. Stackpole Books: Harrisburg, PA, 698pp.

Webb, S.D. (1978). A history of savanna vertebrates in the New World. Part II: South America and the Great Interchange. Annual Review of Ecology, Evolution, and Systematics 9: 393-426.

Willis, B. (1914). El norte de la Patagonia. Ministerio de Obras Publicas: Buenos Aires, Argentina, 500pp.

Spanish Abstract: Con el objeto de contribuir a la conservación del huemul Patagónico (Hippocamelus bisulcus) el grupo de trabajo, Huemul Task Force (HTF), realizó una revisión de la información sobre la morfología apendicular, paleobiogeografía y distribución histórica del huemul como factores potencialmente relevantes en los esfuerzos de recuperación de la especie. La creencia tradicional de que el huemul es un especialista de los hábitats de montaña andinos fue refutada por la evidencia empírica de los análisis morfológicos. La anatomía apendicular del huemul es similar a la de otros cérvidos y difiere de las especializaciones implicadas para la escalada en roca de otros ungulados. Por lo tanto, se apoya la evidencia histórica del huemul en un hábitat sin árboles como la estepa Patagónica. Su presencia histórica en la costa atlántica no puede ser considerada como observaciones erróneas. En su lugar, hay que entender que impactos antropogénicos pre y post colombinos dieron como resultado el desplazamiento de huemul desde los sitios más productivos a sitios de supervivencia, sobre todo en las áreas de refugio remotas y marginales. El proceso de contracción de su rango geográfico se vió facilitado por la caza fácil, por los incentivos energéticos de los ciclos estacionales de las reservas corporales de grasa, por las concentraciones numéricas de huemul, por el cambio de la economía cazador-recolector a una economía ecuestre móvil, y por la colonización con introducción de ganado doméstico. Las áreas de montaña actualmente utilizadas por el huemul, supuesto especialista de estos hábitats, también son ocupadas por ungulados domésticos, que claramente no son especialistas en montaña. Además, el único otro miembro de Hippocamelus utiliza con éxito las áreas homólogos a la región. La aplicación rígida del uso del hábitat moderno para inferir el uso del hábitat pasado, ignorando el hábitat histórico extra-andino es injustificada. Estas conclusiones alcanzadas por el HTF indican nuevas oportunidades para los esfuerzos de recuperación del huemul, apoyadas por la combinación de elementos morfológicos e históricos. Por ejemplo, la reintroducción a otros sectores del paisaje utilizado anteriormente por el huemul, que tienden a ser sitios más productivos que los actualmente ocupados por muchos grupos de huemules, presentaría una vía prometedora. 
Eduardo G. Aisen

Lab. Theriogenology, Universidad Nacional del Comahue, IDEPA (CONICET-UNCo), c.c. 85 8303 Cinco Saltos, Rio Negro

Email: eduardoaisen@hotmail.com

Patricia Black de Decima

Instituto Miguel Lillo, Miguel Lillo 205, 4000

San Miguel de Tucuman, Argentina

Email: patriciablack_decima@hotmail.com, pblack@csnat.unt.ēdu.ar

\section{Werner Flueck}

National Council of Scientific and Technological Research (CONICET), Buenos Aires, Swiss

Tropical and Public Health Institute, University Basel, C.C. 592, 8400 Bariloche, Argentina Email:werner.flueck@unibas.ch

\section{Jo Anne Smith-Flueck}

Institute of Natural Resources Analysis Patagonia, Universidad Atlantida Argentina, C.C. 592, 8400 Bariloche, Argentina Email: j.smith@deerlab.org (corresponding author)

\section{Norberto Tomas}

Parque Nacional Calilegua, San Lorenzo s/n 4514 Calilegua, Jujuy, Argentina

Email: jnorbertotomas@yahoo.com.ar, ntomas@apn.gov.ar

\section{Gladys Garay}

Paraguaya 126, Barrio San Miguel, Punta Arenas, Chile

Email: gladysenviaje@yahoo.com

\section{Jaime E. Jiménez}

University of North Texas, 1155 Union Circle Denton, Texas 76203-5017, USA

Omora Ethnobotanical Park, Universidad de

Magallanes, Puerto Williams, Chile

Email: jaime.jimenez@unt.edu

\section{Fernando Vidal}

Fundación Huilo-Huilo, Vitacura 2909 Of. 1112

Las Condes, Santiago, Chile

Email: fauna.andina@gmail.com

Valerius Geist

PO Box 1294, Station A, Port Alberni, BC, V9Y 7M2, Canada

Email: kendulf@shaw.ca

\section{Zygmunt Gizejewski}

Polish Academy of Sciences, Institute of Animal Reproduction and Food Research, PI-10-747 Olsztyn, Poland

Email: z.gizejewski@pan.olsztyn.pl 